\title{
Clinical Aspects of Parathyroid Hyperplasia in Secondary Renal Hyperparathyroidism
}

\author{
Costin Pasnicu, Petru Adrian Radu, Dragos Garofil, Iustin Bengulescu, Vlad Paic, Anca Tigora, Florian Popa, \\ Victor Strambu, Mircea Bratucu
}

Department of Surgery, Carol Davila Clinical Hospital of Nephrology, Bucharest, Romania

Corresponding author:

Petru Adrian Radu, MD

Department of Surgery

Carol Davila Clinical Hospital of

Nephrology, Bucharest, Romania

E-mail: drradupetru@yahoo.com

\section{Abbreviations:}

HPT - Hyperparathyroidism;

SHPT - Secondary Hyperparathyroidism

PTH - Parathyroid Hormone:

PTH - Parathormone;
Received: 28.08 .2019

Accepted: 03.10.2019

\section{Rezumat}

Aspecte clinice ale hiperplaziei paratiroidiene în hiperparatiroidismul secundar de cauză renală

Hiperparatiroidismul secundar de cauză renală (sHPT) afectează într-o măsură mai mică sau mai mare, la toți pacienții cu boală cronică de rinichii. Această patologia este severă întrucât survine la un pacient tarat, la care boala cronică de rinichi se asociază frecvent cu multiple comorbidități severe, astfel mortalitatea este mai mare față de populația generală. Eşecul conduitei medicale reprezintă o indicație pentru efectuarea tratamentului chirurgical. Recurența bolii, în hiperparatiroidismul secundar de cauză renală, după tratamentul chirurgical prin paratioridectomie totală cu autotransplant sau paratiroidectomie subtotală poate reprezenta 0 provocare datorită hiperplazierii tesutului restant sau hiperplazierea autogrefelor. Scopul acestui studiu retrospectiv a fost de a evidenția factorii de risc pentru apariția hiperplaziei glandulare în cazul pacienților cu hiperparatiroidism secundar de cauză renală şi de a determina standardizarea tratamentulul chirurgical pentru hiperparatiroidismul secundar în vederea minimizării ratelor de recidivă. Astfel, pacienții cu sHPT ar putea fi scutiți de administrarea prelungită şi continuă a medicamentelor, care ar provoca hipoparatiroidism intolerabil odată cu intervenția chirurgicală extensivă (19). Evaluare dimensiunii paratiroidiene poate sugera prezența hiperplaziei nodulare contribuind la efectuarea unei paratiroidectomii timpurii şi totodată la alegerea tratamentului chirurgical optim pentru pacienții sHPT. Intrucât rezistența la terapia medicală este dată de prezența hiperplaziei nodulare unii 
autori indică paratiroidectomia subtotală cu excizia acestor glandele, urmând ca paratiroidele restante sa fie controlate prin terapie medicală (20).

Cuvinte cheie: hiperparatiroidism secundar, insuficiență renală cronică, paratiroidectomie, stereomicroscopie

\section{Abstract}

The secondary hyperparathyroidism (sHPT) affects all patients with chronic renal failure in different degrees. The chronic kidney disease is often associated with multiple severe comorbidities, therefore the figures for mortality are higher than in the general population. The failure of medical treatment is an indication for surgical treatment. The recurrence of the disease in secondary hyperpara-thyroidism after surgical treatment using total parathyroid with autotransplantation or subtotal parathyroidectomy may be a challenge due to hyperplasia of the remaining tissue. The purpose of this retrospective study was to highlight the risk factors for the occurrence of glandular hyperplasia in patients with secondary hyperparathyroidism and to determine optimal surgery approach for secondary hyperparathyroidism in order to minimize relapse rates. Parathyroid size evaluation may suggest the presence of nodular hyperplasia contributing to an early parathyroidectomy and at the same time selecting the best surgical treatment for sHPT patients. As resistance to medical therapy is due to the presence of nodular hyperplasia, some authors recomends subtotal parathyroidectomy with the excision of these glands, with the remaining parathyroids tissue and function controlled by medical therapy (20).

Key words: secondary hyperparathyroidism, chronic renal failure, paratiroidectomy, stereomicroscopy

\section{Introduction}

Secondary hyperparathyroidism (sHPT) is a complication of chronic kidney disease and is characterized by the increase values of parathyroid hormone (PTH) caused by parathyroid gland hyperplasia. The impact of urinary phosphate excretion and hyperphosphatemia, along with low vitamin D levels associated to chronic kidney disease, promotes hypocalcemia and continuous overload of parathyroid glands, inducing their hyperplasia and hypersecretion of HPT.

In most cases, this complication can be successfully controlled by conducting dialysis and medication (phosphate chelators, calcium supplements, vitamin $\mathrm{D}$, vit $\mathrm{D}$ analogues or calcimimetics) (1).
Patients with sHPT develops changes in mineral metabolism and bone damage, leading to increased morbidity and decreased quality of life (2).

These disorders in mineral and bone metabolism are associated with an increased risk of cardiovascular calcification, thus contributing to an increase in morbidity and mortality (3).

With delayed surgical treatment, changes occur in calcium and vitamin $\mathrm{D}$ receptors, favouring nodular hyperplasia and intraglandular adenomatous changes, development of autonomous parathyroid tissue and difficult control by drugs treatment (2).

Performing parathyroidectomy is necessary when hyperparathyroidism becomes refractory to drug therapy, and the rate of surgical 
approach has been reported to be $15 \%$ after 10 years and 38\% after 20 years of dialysis (3).

Various surgical techniques for the treatment of sHPT have been described, but the optimal choice of surgical treatment for elderly patients who are not eligible for renal transplantation remains controversial $(5,6)$.

Total parathyroidectomy was discussed and develop serious risk of adynamic bone disease, extrascheletal calcifications and permanent hypocalcaemia requiring long-term calcium and vitamin $\mathrm{D}$ administration (7).

Total paratiroidectomy improves the symptoms and signs of sHPT increasing the survival rate and the quality of life of the patients (2).

Patients with sHPT develop hyperplasic glandular nodes. Hyperplasia of parathyroid tissue progresses irreversibly $(8,9)$ from diffuse hyperplasia to nodular hyperplasia, being classified into four categories: diffuse hyperplasia, mixed hyperplasia, nodular hyperplasia and glandular solitary node $(10,11)$.

Initially, the cell growth is diffuse, polyclonal, so that hyperplasia becomes nodular and proliferates (12-15). This process is influenced by the duration of kidney dialysis. At the same time, it should be a correlation between total glandular mass and HPT (16).

sHPT refractory to drug therapy is due to the presence of parathyroid tissue with nodular hyperplasia (17).

An analysis of the relation between the size of the parathyroid glands and the histopathological examination showed that in the nodular hyperplasia the volume of the parathyroid glands is greater than $300 \mathrm{~mm}^{3}$, and a diameter greater than $8 \mathrm{~mm}$ (18).

The purpose of this study was to identify the risk factors for the occurrence of glandular hyperplasia in patients with secondary hyperparathyroidism of the renal cause.

Although, patients with sHPT could be relieved from prolonged and continuous administration of drugs and would cause intolerable hypo parathyroidism with extensive surgery (19).

As resistance to medical therapy is due to the presence of nodular hyperplasia, some authors indicate subtotal parathyroidectomy with the excision of these glands so that the others can be controlled by medical therapy (20).

\section{Materials and Methods}

A performed retrospective study analyzed a group of 80 patients with sHPT and chronic kidney disease accepted in our clinic between January 2015 and December 2017.

All patients underwent surgery approach. Surgical intervention was indicative of failure of medical therapy (repeated HPT values above $800 \mathrm{pg} / \mathrm{ml}$, which add hypercalcemia, hyperphosphatemia / persistence of symptoms).

From the total of 80 patients, two subgroups were analised, depending on the type of hyperplasia: diffuse hyperplasia A $(n=40)$ (Table 1) and nodular hyperplasia B $(n=40)$ (Table 2).

The study was approved by the institutional ethics committee (Carol Davila Clinical Hospital of Nephrology) and informed consent was obtained from all patients.

80 total parathyroidectomies were performed.

Table 1. Demographic, clinical and laboratory characteristics of the patients included in subgroup $A$

\begin{tabular}{lc}
\hline Diffuse hyperplasia & (N=40) \\
\hline Women / Men & $24 / 16$ \\
\hline Age (years) & $51(38-61)$ \\
\hline Weight PT (g) & $0,72(0,55-0,93)$ \\
\hline Average PT volume (mm $)$ & 691 \\
\hline Average preoperative PTH (pg / ml) & 1310 \\
& $(894.174-1691.361)$ \\
\hline Average duration of dialysis (years) & $4,1(0-13,7)$ \\
\hline Peritoneal hemodialysis / dialysis & $34 / 6$ \\
\hline Creatinine (mg / dl) & $7,18(5,1-9,1)$ \\
\hline Transferin mg / dl & $151,81(16-581)$ \\
\hline Alkaline phosphatase u / & $206(26-1412)$ \\
\hline Serum urea (mg / dl) & $157(129-216)$ \\
\hline Ca (mg / dl) & $9.12(8.71-10.64)$ \\
\hline As I (mg / dl) & $4.74(4.58-5.27)$ \\
\hline Phosphorus (mg / dl) & $14.82(7.27-30.29)$ \\
\hline BMl kg / m ${ }^{2}$ & $25.9(16.8-41.7)$ \\
\hline
\end{tabular}


Table 2. Demographic, clinical and laboratory characteristics of the patients included in subgroup $B$

\begin{tabular}{lc}
\hline Nodular hyperplasia & $(\mathrm{N}=40)$ \\
\hline Women / Men & $22 / 18$ \\
\hline Age (years) & $57(46-69)$ \\
\hline Weight PT (g) & $1,98(1,72-3,16)$ \\
\hline Average PT volume $\left(\mathrm{mm}^{3}\right)$ & 1272 \\
\hline Preoperative PTH (pg / ml) & 1732 \\
& $(961.043-2829.63)$ \\
\hline Average duration of dialysis (years) & $5,8(0-15,2)$ \\
\hline Peritoneal hemodialysis / dialysis & $40 / 0$ \\
\hline Creatinine (mg / dl) & $7,63(5,7-10,46)$ \\
\hline Transferin mg / dl & $158,63(17-671)$ \\
\hline Alkaline phosphatase & $258(31-1612)$ \\
\hline Serum urea (mg / dl) & $162(136-241)$ \\
\hline Ca (mg / dl) & $9.81(9.03-10.91)$ \\
\hline As I (mg / dl) & $5.02(4.87-5.62)$ \\
\hline Phosphorus (mg / dl) & $15.47(7.42-30.68)$ \\
\hline BMl kg / m ${ }^{2}$ & $25.4(16.1-40.8)$ \\
\hline
\end{tabular}

Parathyroid tissue was analyzed using stereomicroscopy using Olympus SZX16 equipment (Total Magnification 2.1x-690x; Zoom Ratio16.4 (0.7x-11.5x) and using a dual, tangential light source (Olympus KL 1600) (Fig. 1, 2)

Subsequently, the results were confirmed following an anatomopathological examination (Fig. 3, 4).

The glandular volume was determined by the complete immersion of resected tissue in a graduated cylinder filled with demineralized water.

\section{Results}

Gender distribution was $46(57.5 \%)$ women and $34(42.5 \%)$ men. The highest incidence of

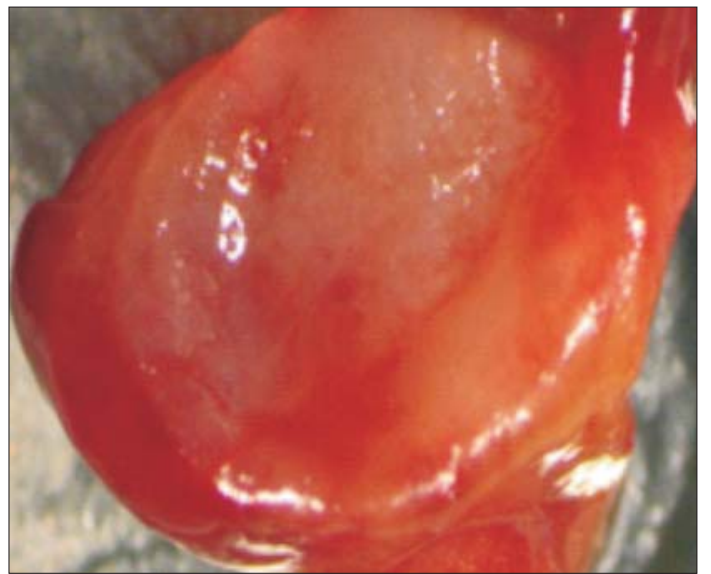

Figure 1. Stereomicroscopic image (diffuse hyperplasia)

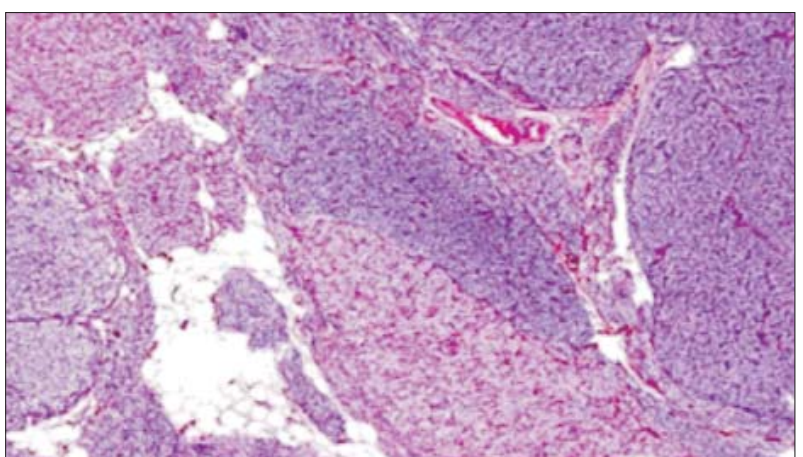

Figure 3. Diffuse hyperplasia with principal, oxyphile and transient cells with stromal fatty changes

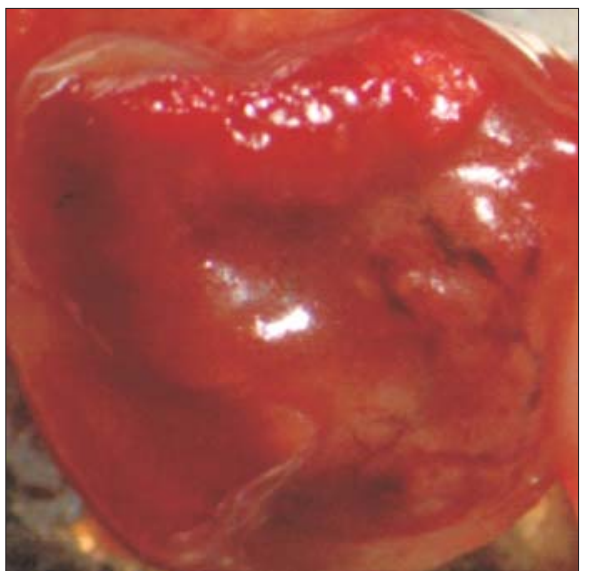

Figure 2. Stereomicroscopic image (nodular hyperplasia)

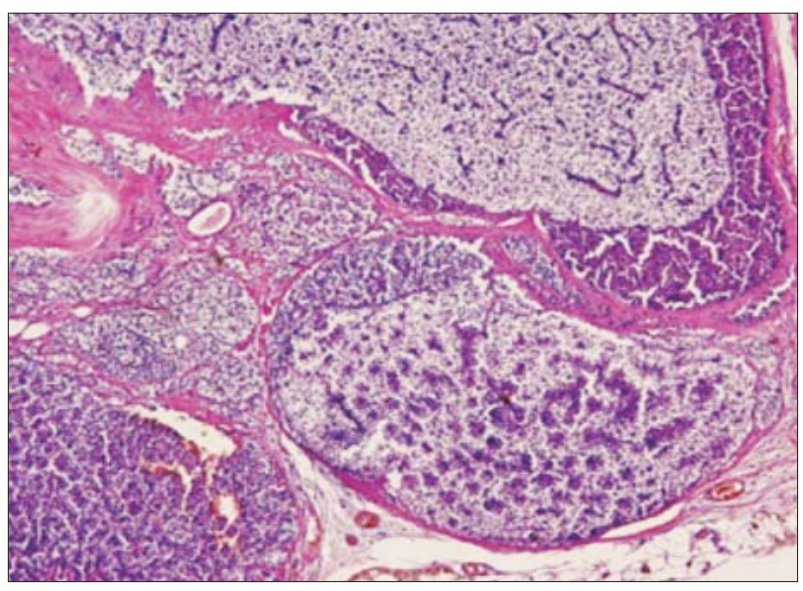

Figure 4. Nodular hyperplasia 
the disease was present at ages between 40 and 60 years, with 49 patients, representing $61.5 \%$. The average age of patients with diffuse hyperplasia was 51 years with a range between 38-61 years, and in the case of those with nodular hyperplasia it was 57 years with a range between 46-69 years. From the 80 patients there were 6 patients with peritoneal dialysis and who had diffuse hyperplasia of the parathyroid glands.

There was a case with the presence of 5 parathyroid glands confirmed anatomopathologically. The inability to isolate four parathyroid glands (Fig. 5) was considered incomplete surgery and was excluded from the study.

Ectopic parathyroid gland was found 3 cases $(3.75 \%) ; 2(2.5 \%)$ cases with anterior mediastinal localization and 1 case $(1.25 \%)$ intratyroid localization.

The presence of the $5^{\text {th }}$ parathyroid gland in the case of the supernumerary parathyroid was with previous mediastinal localization.

The symptoms were dominated by osteoarticular pain, muscle pain, asthenia and fatigue present in all cases in the clinical trial. In $30 \%$ of cases itching occurred in varying degrees of intensity. Other disorders included mood swings, irritability and depression (17.5\% - 14 patients).

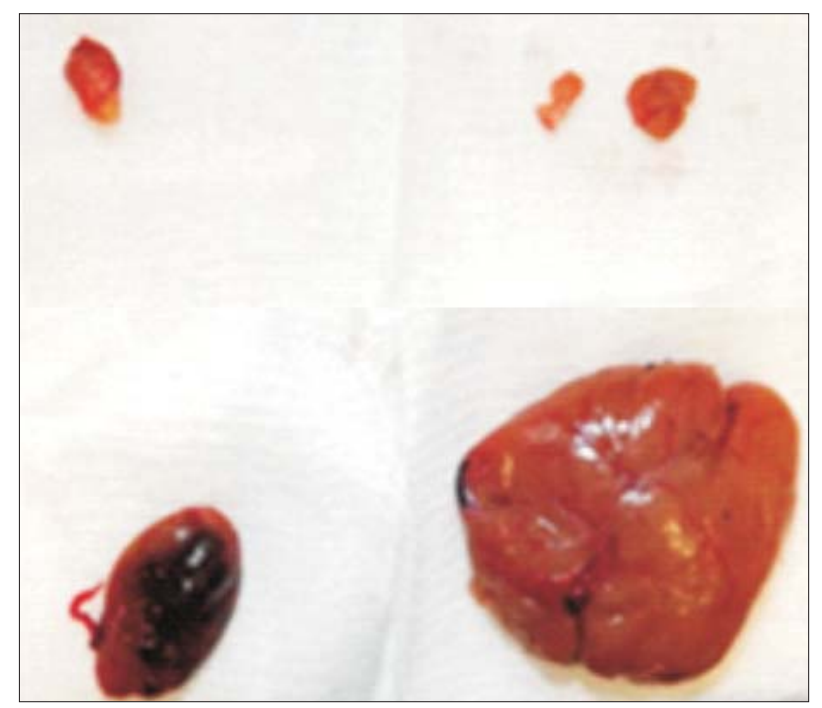

Figure 5.
In the case of subgroup A the weight of the excised glands was between 0.55-0.93 grams with an average of $0.72 \mathrm{~g}$, and in the case of subgroup B it was between 1.72-3.16 g with an average of $1,98 \mathrm{~g}$. The average volume in the case of subgroup A was $691 \mathrm{~mm} 3$ and in the case of subgroup B $1272 \mathrm{~mm}^{3}$.

The average preoperative value of parathormone (PTH) in subgroup A was 1410 $\mathrm{pg} / \mathrm{ml}$ (normal values $17.3-73 \mathrm{pg} / \mathrm{ml}$ ); most cases (28 patients - 70\%) had preoperative values exceeding $1000 \mathrm{pg} / \mathrm{ml}$ PTH. The mean serum creatinine value in this subgroup was $7.23 \mathrm{mg} / \mathrm{dL}$.

The average preoperative value of parathormone (PTH) in subgroup B was 1632 pg / ml; most patients (31 cases - 77.5\%) had preoperative values of over $1000 \mathrm{pg} / \mathrm{ml} \mathrm{PTH}$. The average serum creatinine value in this subgroup was $7.18 \mathrm{mg} / \mathrm{dL}$.

A significant decrease in PTH was observed in all cases of total parathyroidectomy (PTH mean postoperatively value $21.54 \mathrm{pg} / \mathrm{ml}$ ). The immediate postoperative serum calcium had a decreasing tendency and necesitate medical correction.

The average duration of haemodialysis in subgroup B was 5.8 years compared to 4.1 years in subgroup A. Among those in subgroup A, there were 6 patients with peritoneal dialysis.

Serum creatinine in patients in subgroup A had a mean value of $7.18 \mathrm{mg} / \mathrm{dl}$ with a minimum of $5.1 \mathrm{mg} / \mathrm{dl}$ and a maximum of 9.1 $\mathrm{mg} / \mathrm{dl}$, and within subgroup B an average of $7.63 \mathrm{mg} / \mathrm{dl}$, with a minimum of $5.7 \mathrm{mg} / \mathrm{dl}$ and a maximum of $10.46 \mathrm{mg} / \mathrm{dl}$.

The value of transferin in patients in subgroup A had an average value of $151.81 \mathrm{mg} /$ $\mathrm{dl}$ with a minimum of $16 \mathrm{mg} / \mathrm{dl}$ and a maximum of $581 \mathrm{mg} / \mathrm{dl}$, and within the subgroup B an average of $158.63 \mathrm{mg} / \mathrm{dl}$, with a minimum of $17 \mathrm{mg} / \mathrm{dl}$ and maximum of $671 \mathrm{mg} / \mathrm{dl}$.

The value of alkaline phosphatase in patients in subgroup A had a mean value of $206 \mathrm{u} / \mathrm{l}$ with a minimum of $26 \mathrm{u} / \mathrm{l}$ and a maximum of $1412 \mathrm{u} / \mathrm{l}$, and within subgroup B an average of $258 \mathrm{u} / \mathrm{l}$, with a minimum of 31 $\mathrm{u} / \mathrm{l}$ and maximum of $1612 \mathrm{u} / \mathrm{l}$.

Serum urea in patients in subgroup A had 
a mean value of $157 \mathrm{mg} / \mathrm{dl}$ with a minimum of $129 \mathrm{mg} / \mathrm{dl}$ and a maximum of $216 \mathrm{mg} / \mathrm{dl}$, and within subgroup B an average of $162 \mathrm{mg} /$ $\mathrm{dl}$, with a minimum of $136 \mathrm{mg} / \mathrm{Mon}$ and maximum of $241 \mathrm{mg} / \mathrm{Mon}$.

Serum calcium $(\mathrm{Ca})$ in patients in subgroup A had a mean value of $9.12 \mathrm{mg} / \mathrm{dl}$ with a minimum of $8.71 \mathrm{mg} / \mathrm{dl}$ and a maximum of $10.64 \mathrm{mg} / \mathrm{dl}$, and within subgroup B an average of $9.81 \mathrm{mg} / \mathrm{dl}$, with a minimum of $9.03 \mathrm{mg} / \mathrm{dl}$ and a maximum of $10.91 \mathrm{mg} / \mathrm{dl}$. Ion calcium ( $\mathrm{Ca} \mathrm{I}$ ) in patients in subgroup A had a mean value of $4.74 \mathrm{mg} / \mathrm{dl}$ with a minimum of $4.58 \mathrm{mg} / \mathrm{dl}$ and a maximum of $5.27 \mathrm{mg} / \mathrm{dl}$, and in subgroup B of $5.02 \mathrm{mg} / \mathrm{dl}$, with a minimum of $4.87 \mathrm{mg} / \mathrm{dl}$ and a maximum of $5.62 \mathrm{mg} / \mathrm{dl}$.

The body mass index (BMI) was almost equal among patients with diffuse hyperplasia compared to those with nodular hyperplasia.

75 patients (94\% of cases) were investigated by preoperative cervical ultrasonography. Scintigraphy of the parathyroid glands was performed in 18 cases (22.5\% of cases), CT exam of the cervical region in 3 cases $(3.75 \%)$ and MRI in 1 case (1.25\% of cases).

The morbidity rate was represented by 2 (2.5\%) cases with local bleeding complications, 1 case $(1.25 \%)$ with temporary dysphonia; no mortality was recorded.

The average hospitalization was 8.5 days (from 3 to 19 days). The patients were discharged after the normalization of the calcemia, later to be re-evaluated at 6 months postoperatively.

\section{Discussion}

Identifying the risk factors for the occurrence of glandular hyperplasia in patients with sHPT may eliminate the prolonged and continuous administration of the drugs, which would cause intolerable hypoparathyroidism with extensive surgery (19).

Total parathyroidectomy have minimum risk of postoperative relapse $(0-4 \%)(21,22,23)$. The disadvantages of the method are represented by possible post-operative tetanic seizures, the onset of osteopenia, as well as the long-term substitution of calcium and vitamin D.

Total parathyroidectomy with autotransplantation is another option for patients with sHPT. The benefit of this surgical technique lies in maintaining parathyroid tissue capable of secreting paratormone. The disadvantages are represented by the possibility of diffuse seeding of the parathyroid tissue, prolonged postoperative periods of hypocalcemia or the possibility of autoplasty of neoplastic tissue. The recurrence rates of total parathyroidectomy with autotransplantation for sHPT are higher than those found in total parathyroidectomy without autotransplantation, the literature citing the percentages between $8 \%$ and $20 \%$ (24,25). When surgical parathyroidectomy with autotransplantation is chosen as a surgical treatment, nodular parathyroid regions should be avoided, due to its high risk of proliferation, resulting in graft-dependent recurrence, while non-nodular hyperplasia parathyroid areas (autoimmune hyperplasia) are considered eligible (26).

Subtotal parathyroidectomy it can be the third option for patients suffering from sHPT and involves excision of three parathyroid glands and another half (or 3/4) of the fourth; preservation of 40-70 $\mathrm{mg}$ of parathyroid tissue from the fourth gland (usually the lower gland with normal appearance). Short-term postoperative hypocalcemia is an advantage for this surgical method. The disadvantages of this procedures are the possibility of seeding the cervical region with parathyroid cells and in many cases the inability to choose regular, unmodified para-thyroid tissue. Last but not least, the risk of recurrence is higher than that observed in total parathyroidectomy, reaching values up to $20 \%$. The recurrence rates of sHPT are similar to those of total parathyroidectomy with autotransplantation.

An evaluation of the parathyroid size may suggest the presence of nodular hyperplasia, contributing to an early parathyroidectomy and also to choosing the right surgical treatment for patients with secondary hyperparathyroidism.

The indication for the parathyroid intervention can be determined by the number of 
parathyroid glands with nodular hyperplasia, the location of the glands, the existence of the ectopic glands, the locoregional anatomical conformation and the general condition of the patient.

The identified risk factors (duration of dialysis, PG volume and serum PTH level) can be easily incorporated into the daily routine and could be used for non-invasive assessment of the nodular hyperplasia of PG. This evaluation, correlated with a periodic analysis in the dynamics of PG changes during sHPT deployment, would benefit from an optimal choice of medical or surgical sHPT treatment.

The increased serum PTH level is a risk factor independent of PG, but it has a low impact on the occurrence of nodular hyperplasia.

The probability of occurrence of nodular hyperplasia of a parathyroid gland is influenced by the duration of dialysis performed, thus, a prolonged duration of dialysis fundamentally changes the volume of the glands. This high impact on the probability of nodular hyperplasia of PG through dialysis duration is statistically demonstrated for the first time and, therefore, recently based on evidence (16).

Patients refractory to calcimimetic treatment have the highest probability of becoming hyperplastic nodular (29).

The approach of the surgical treatment by local ablation, respectively the targeted intervention on the tissue, probably nodular hyperplasia is indicated in the case of hypoparathyroidism or some contraindications for extended surgical interventions $(15,23,30)$.

\section{Conclusions}

In conclusion, analysis in the dynamics of $\mathrm{PG}$ changes during sHPT deployment should benefit from an optimal choice of medical or surgical sHPT treatment, thus avoiding prolonged pharmacological treatment, without chance of success, or the occurrence of hypoparathyroidism given by total parathyroidectomy, by delaying surgical treatment.

As current treatment we can combine the surgical treatment of nodular hyperplastic glands, so that we can later pharmacologically control the remaining parathyroid tissue.

\section{Conflict of Interest}

The authors declare no conflicts of interests.

\section{References}

1. Felsenfeld AJ, Considerations for the treatment of secondary hyperparathyroidism in renal failure. J Am Soc Nephrol. 1997; 8:993-1004

2. Bratucu MN, Garofil ND, Radu PA, Paic V, Goleanu V, Zurzu M, et al. Measurement of Quality of Life after Total Parathyroidectomy in Patients with Secondary Hyperparathyroidism and End Stage Renal Disease. Chirurgia (Bucur). 2015;110(6):511-7.

3. Block GA, Cunningham J. Morbidity and mortality associated with abnormalities in bone and mineral metabolism in CKD. In: Olgaard $\mathrm{K}$ (ed) clinical guide to the basics of bone and mineral metabolism in CKD. National Kidney Foundation, New York. 2006; p 77-92.

4. Fassbinder W, Brunner FP, Brynger H, Ehrich JH, Geerlings W, Raine $A E$, et al. Combined report on regular dialysis, transplantation in Europe, XX, 1989. Nephrol Dial Transplant. 1991;6 Suppl 1:5-35.

5. Drakopoulos S, Koukoulaki M, Apostolou T, Pistolas D, Balaska K, Gavriil S, et al. Total parathyroidectomy without autotransplantation in dialysis patients and renal transplant recipients, long-term follow-up evaluation. Am J Surg. 2009;198(2):178-83.

6. Iwamoto N1, Sato N, Nishida M, Hashimoto T, Kobayashi H, Yamasaki S, et al. Total parathyroidectomy improves survival of hemodialysis patients with secondary hyperparathyroidism. J Nephrol. 2012;25(5):755-63.

7. Messa P. Italian society of nephrology, (Renal osteodystrophy Guidelines). G Ital Nefrol. 2003; 24:S83-S95

8. Tominaga $Y$, Tanaka $Y$, Sato $K$, Nagasaka T, Takagi $H$. Histopathology, pathophysiology, and indications for surgical treatment of renal hyperparathyroidism. Semin. Surg. Oncol. 1997; $13: 78 \pm 86$.

9. Goto S, Komaba H, Fukagawa M. Pathophysiology of parathyroid hyperplasia in chronic kidney disease: preclinical and clinical basis for parathyroid intervention. NDT Plus. 2008;1:iii2 \pm iiiz.

10. Tominaga $Y$, Sato K, Tanaka Y, Numano M, Uchida K, Takagi H. Histopathology and pathophysiology of secondary hyperparathyroidism due to chronic renal failure. Clin Nephrol. 1995;44 Suppl 1:S42-7.

11. Parfitt AM. The hyperparathyroidism of chronic renal failure: $A$ disorder of growth. Kidney Int. 1997; 52 (1):3ะ9. PMID: 9211340.

12. Badiu C, Stanescu B, Chirurgie endocrina cervicala. Bucuresti: Editura Academiei Române; 2005.

13. Tominaga Y, Matsuoka S, Uno N. Surgical and Medical Treatment of Secondary Hyperparathyroidism in Patients on Continuous Dialysis. World J Surg. 2009;33:2335-2342.

14. Tominaga Y, Kohara S, Namii Y, Nagasaka T, Haba T, Uchida K,et al. Clonal analysis of nodular parathyroid hyperplasia in renal hyperparathyroidism. World J Surg. 1996;20(7):744-50.

15. Tominaga Y. Mechanism of parathyroid tumourigenesis in uraemia. Nephrol Dial Transplant. 1999;14 Suppl 1:63-5.

16. Malmaeus J, Grimelius L, Johansson H, Akerström G, Ljunghall S. 
Parathyroid pathology in hyperparathyroidism secondary to chronic renal failure. Scand J Urol Nephrol. 1984;18(2):157-66.

17. Tominaga Y, Matsuoka S, Sato T, Uno N, Goto N, Katayama A, et al. Clinical features and hyperplastic patterns of parathyroid glands in hemodialysis patients with advanced secondary hyperparathyroidism refractory to maxacalcitol treatment and required parathyroidectomy. Ther. Apher. Dial. 2007;11:266 \pm 273 .

18. Matsuoka S, Tominaga Y, Sato T, Uno N, Hiramitu T, Goto N, et al. Relationship between the dimension of parathyroid glands estimated by ultrasonography and the hyperplastic pattern in patients with renal hyperparathyroidism. Ther. Apher. Dial. 2008; $12: 391 \pm 395$.

19. Lorenz K, Bartsch DK, Sancho JJ, Guigard S, Triponez F. Surgical management of secondary hyperparathyroidism in chronic kidney disease-a consensus report of the European Society of Endocrine Surgeons. Langenbecks Arch Surg. 2015; 400:907 \pm 927 .

20. Fukagawa M, Tominaga $Y$, KitaokaM, Kakuta $T$, Kurokawa $K$. Medical and surgical aspects of parathyroidectomy. Kidney Intb.1999;56(Suppl. 73):S65-S69.

21. Madorin C, Owen RP, Fraser WD, Pellitteri PK, Radbill B, Rinaldo A, et al. The surgical management of renal hyperparathyroidism. Eur
Arch Otorhinolaryngol.2012; 269(6):1565-76.

22. Lorenz K, Ukkat J, Sekulla C, Gimm O, Brauckhoff M, Dralle H. Total parathyroidectomy without autotransplantation for renal hyperparathyroidism: experience with a qPTH-controlled protocol. World J Surg. 2006;30:743-751.

23. Stracke S, Jehle PM, Sturm D, Schoenberg MH, Widmaier U, Beger $\mathrm{HG}$, et al. Clinical course after total parathyroidectomy without autotransplantation in patients with end-stage renal failure. Am J Kidney. 1999;33:304-311.

24. Tominaga $\mathrm{Y}$, Uchida K, Haba T, Katayama A, Sato T, Hibi Y, et al. More than 1,000 cases of total parathyroidectomy with forearm autograft for renal hyperparathyroidism. Am J Kidney Dis. 2001;38 4 Suppl. 1:S168-71.

25. Ohe MN, Santos RO, Neves MC, Carvalho AB, Kunii IS, Abrahăo M, et al. Autotransplant tissue selection criteria with or without stereomicroscopy in parathyroidectomy for treatment ofrenal hyperparathyroidism. Braz J Otorhinolaryngol. 2014;80(4):318-24

26. U. Neyer, H. Hoerandner, A. Haid, G. Zimmermann, B. Niederle. Total parathyroidectomy with autotransplantation in renal hyperparathyroidism: low recurrence rates after intra-operative tissue selection. Nephrol Dial Transplant; 17.2002; p. 625-629. 